\title{
FILTRASI BANTARAN SUNGAI, FBS DAN FILTRASI BANTARAN DANAU, FBS/D UNTUK SUMBER DAYA AIR BERKELANJUTAN
}

\section{RIVERBED FILTRATION, FBS AND LAKEBED FILTRATION, FBS/D FOR SUSTAINABLE WATER RESOURCES}

\author{
S. Syafalni ${ }^{1}$, W. Marsiano ${ }^{2}$, dan Wawan Kuswaya ${ }^{3}$ \\ ${ }^{1}$ Institut Sains dan Teknologi Nasional-Jakarta, Email: Syafalni.s@istn.ac.id \\ ${ }^{2}$ Institut Sains dan Teknologi Nasional-Jakarta \\ ${ }^{3}$ Institut Sains dan Teknologi Nasional-Jakarta
}

\begin{abstract}
ABSTRAK
Beberapa pengolahan dengan teknologi canggih telah dikembangkan dan diaplikasikan untuk mengolah air yang berkualitas. Tujuan dari teknologi filtrasi bantaran sungai dan danau/situ dalam pengaliran air tersebut meliputi proses adsorpsi, pertukaran ion, filtrasi dan pengolahan melewati lapisan akuifer tanah sehingga menghasilkan air bersih/minum. Filtrasi bantaran sungai, FBS dan fitrasi bantaran danau/situ, FBD merupakan teknologi yang efisien dan alternatif alami murah untuk memproses air sungai /air permukaan. Selama infiltrasi dan bagian tanah, air permukaan terkena kombinasi fisik, kimia, dan proses biologis seperti filtrasi, pengenceran, penyerapan, dan biodegradasi yang di dapat secara signifikan untuk meningkatkan kualitas air baku untuk kebutuhan air. Pelaksanaan metode ini akan dapat menghindari dampak pencemaran dan penurunan muka air tanah yang pada akhirnya dapat memenuhi permintaan dengan mengintegrasikan pemanfaatan air sungai dan air tan ah dangkal. Berdasarkan hasil penelitian untuk area FBS dan FBD didapatkan dengan perencanaan sumur bor pada bantaran sungai dan Situ menunjukkan kualitas air yang didapatkan termasuk air kelas A untuk bantaran Sungai dan Danau/Situ dengan jarak pengambilan adalah 10 meter atau lebih secara vertical dan horizontal, kecuali untuk $\mathrm{pH}$ air saat pengambilan.
\end{abstract}

Kata Kunci : Airtanah dangkal, Filtrasi bantaran sungai/danau, air minum.

\begin{abstract}
Several treatments with advanced technology have been developed and applied to treat quality water. The purpose of riverbanks and lakes/situ filtration technology in the flow of water includes the adsorption process, ion exchange, filtration and processing through the soil aquifer layer to produce clean/drinking water. Riverbank filtration, FBS and lakeside/situ filtration, FBD is an efficient technology and an inexpensive natural alternative to process river water/surface water. During infiltration and soil passage, surface water is exposed to a combination of physical, chemical, and biological processes such as filtration, dilution, absorption, and biodegradation that can significantly improve the quality of raw water for water requirements. The implementation of this method will be able to avoid the impact of pollution and groundwater subsidence which in the end can meet demand by integrating the use of river water and shallow groundwater. Based on the results of the research for the FBS and FBD areas, it was obtained by planning drilled wells on riverbanks and Situ indicating the quality of the water obtained including class A water for Riverbanks and Lakes/Situ with a withdrawal distance of 10 meters or more vertically and horizontally, except for $\mathrm{pH}$ water at the time of collection..
\end{abstract}

Keyword: Shallow groundwater, river/lake bank filtration, drinking water. 


\section{Pendahuluan}

Perkembangan suatu kota sudah tentu akan meningkatkan jumlah penduduk dan sebagai akibatnya akan meningkatkan keperluan pada pasokan dan tersedianya air yang berkualitas baik untuk kebutuhan masyarakat, industri dan pertanian. Untuk saat ini beberapa teknologi pengolahan lanjut telah dikembangkan dan diterapkan oleh perusahaan air minum untuk mengolah air berkualitas. Teknologi pengolahan tersebut termasuk metode-metode adsorpsi, pertukaran ion, filtrasi membran, pengolahan air tanah, dan teknik oksidasi lanjut. Meskipun efektivitas teknologi ini, ada tantangannya secara luas untuk aplikasinya pada negara-negara berkembang. Hal ini terutama disebabkan biaya untuk mengolahnya dalam jumlah besar, biaya yang dikeluarkan untuk mengolah secara besar-besaran air akan sangat tidak ekonomis. Sebagai alternatif baru metode pengolahan air sangat diperlukan untuk memenuhi kebutuhan dengan semakin meningkatnya kebutuhan konsumsi air. Filtrasi bantaran Sungai, FBS dan Filtrasi Bantaran Danau (Situ), yang disingkat FBD adalah teknologi yang efisien dan alternatif alami untuk pengembangan yang murah terhadap air sungai /air permukaan dan merupakan metode lama untuk memperoleh pasokan air minum dengan menggunakan kapasitas sub-permukaan dekat bantaran sungai sebagai filter alami di mana air sungai / danau diambil pada bantaran menggunakan sumur pompa. Selama infiltrasi dan bagian tanah, air permukaan terkena kombinasi fisik,kimia, dan proses biologis seperti penyaringan, pengenceran, penyerapan, dan biodegradasi yang dapat secara signifikan meningkatkan kualitas air baku untuk kebutuhan air dalam konsumsi domestik, pertanian dan industri. Untuk pemahaman proses yang lebih baik dan kondisi FBD dalam sistem akuifer adalah dengan melakukan penelitian di sepanjang Daerah Aliran Sungai, DAS dan Danau/Situ dengan teknik geofisika dan isotop alam dalam hubungannya dengan metode hidrokimia yang dapat menjelaskan kondisi daerah penelitian.

Dengan bertambahnya penduduk dan berkembangnya industri di kota-kota akan terjadi peningkatan pencemaran sehingga ketersediaan air bersih dan air minum semakin kritis dan perlu dicarikan alternatif sumberdaya air. Seperti yang dilakukan negara maju, pengembangan bantaran sungai atau danau, FBD merupakan suatu potensi yang sangat baik untuk diterapkan sehingga kebutuhan air perkotaan dan desa dapat dipenuhi dan merupakan sumberdaya yang berkelanjutan.

Tujuan dari penelitian untuk mengetahui pontensi FBS/D untuk pengambilan air tanah dangkal sebagai sumberdaya air yang berkelanjutan untuk daerah perkotaan dan desa.

\section{Metodologi Penelitian}

\subsection{Lokasi Penelitian}

Daerah penelitian untuk FBS terletak di Alor Pongsu, bagian dari Skema irigasi Kerian daerah Perak, Malaysia merupakan skema irigasi untuk lumbung nasional yang berlokasi di ujung Barat Utara Negara Bagian Perak, meliputi daearah seluas 23.359 hektar lahan Gambar 1 .

Daerah penelitian untuk FBD terletak di Danau / Situ Kampus ISTN, Srenseng Sawah, Jl. M. Kahfi II, Jakarta Selatan seperti dapat dilihat pada Gambar 2. 
Jurnal SEOI - Fakultas Teknik Universitas Sahid Jakarta

Vol 1 edisi 1 tahun 2019

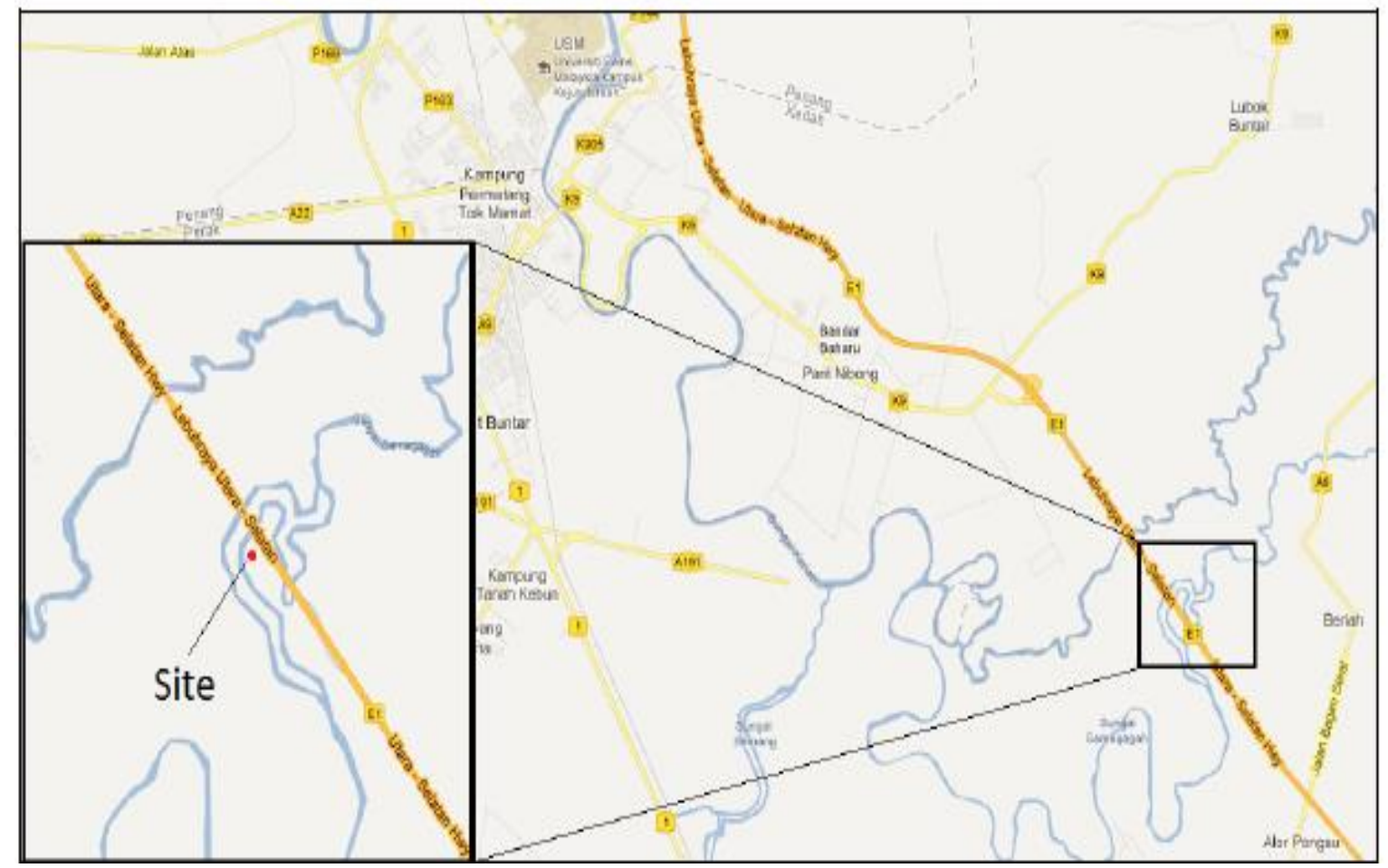

Gambar 1. Lokasi Penelitian di Alor Pongsu, Malaysia (Leong et al. 2014)

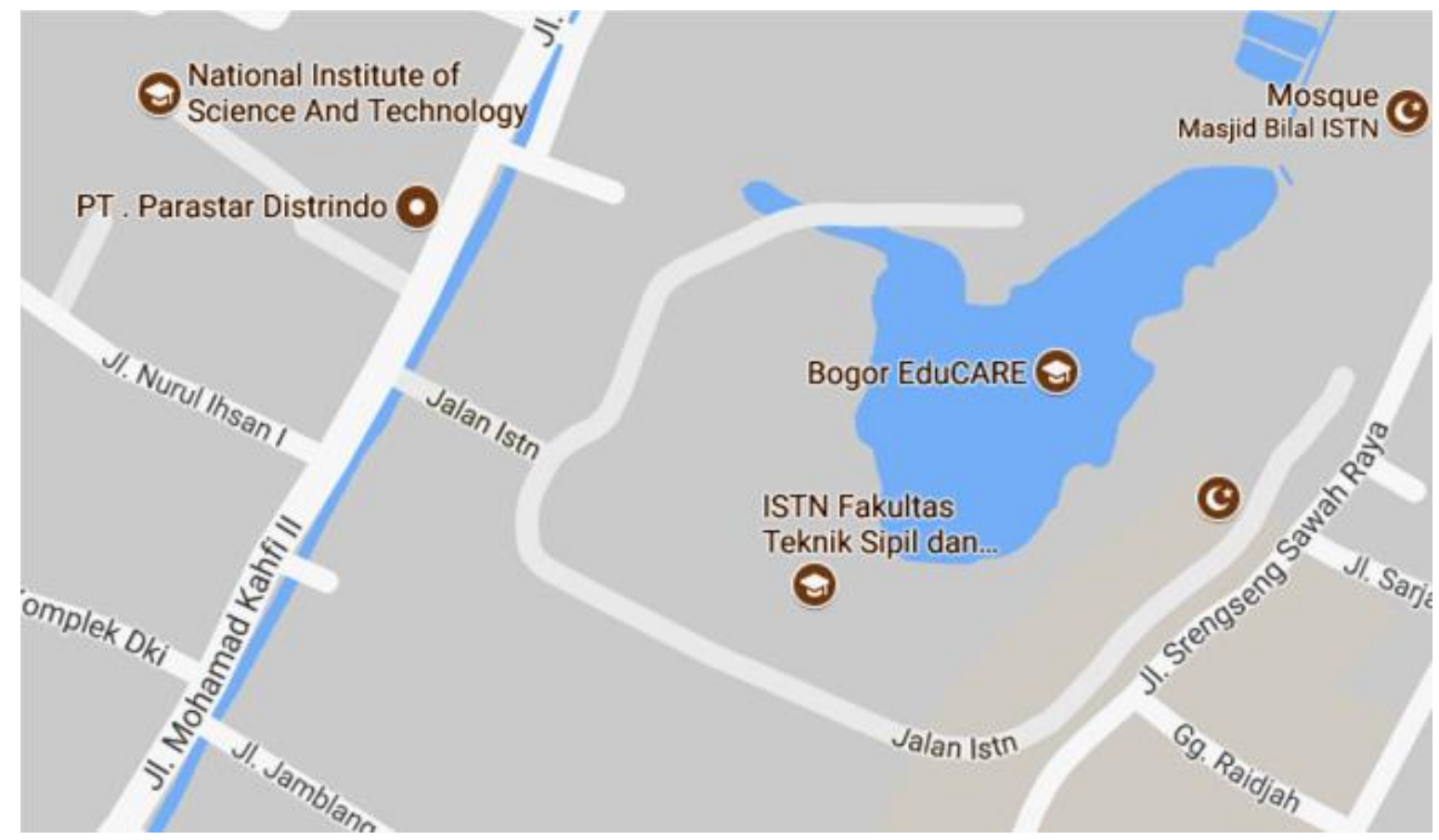

Gambar 2. Lokasi titik pengeboran di Danau ISTN-Jakarta

Kegiatan ini dilaksanakan untuk pemonitoran dan evaluasi kandungan bahan yang efektif setelah peningkatan kualitas air sungai melalui perlakuan permukaan dan sumur FBS buatan menjadi air minum serta melaksanakan pengujian hasil peningkatan kualitas air yang diambil dari hasil perlakuan permukaan dan FBS/D sampai didapatkannya kualitas air yang dipakai untuk perbaikan kualitas air untuk dikonsumsi dengan perencanaan percobaan sbb, (Gambar 3.) 
Jurnal SEOI - Fakultas Teknik Universitas Sahid Jakarta

Vol 1 edisi 1 tahun 2019

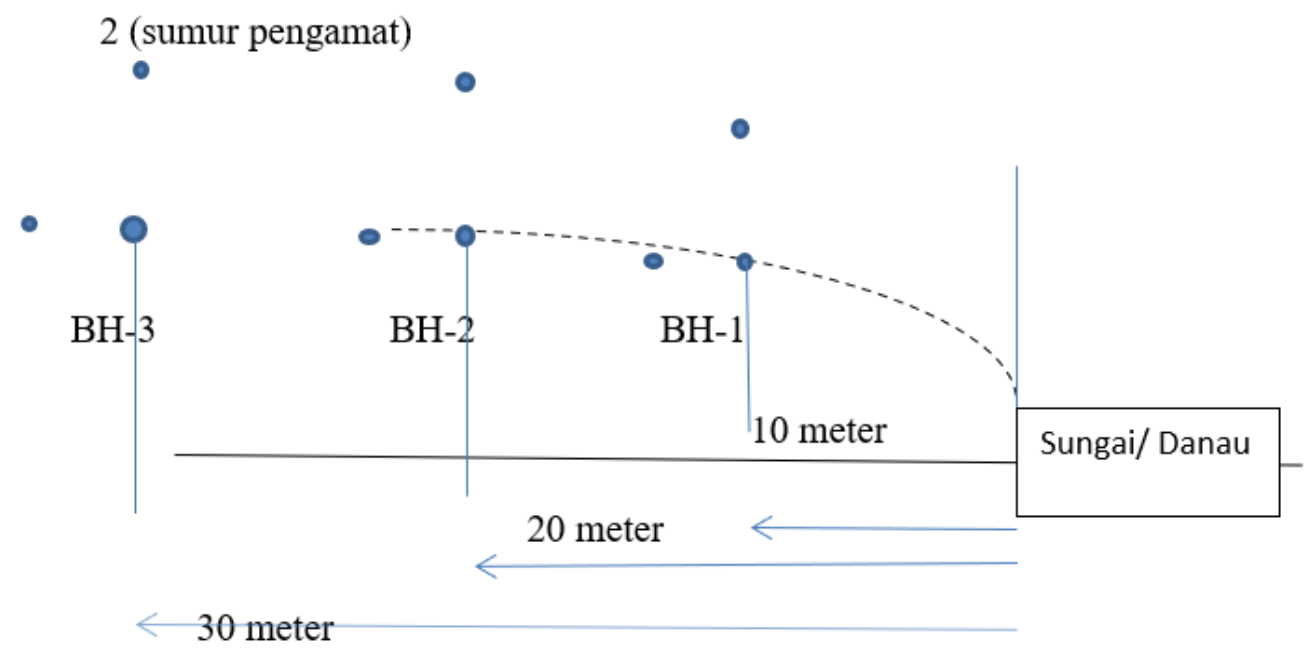

Gambar 3. Rancangan Penelitian untuk Karakteristik Bawah permukaan

\subsection{Teknik Pengumpulan Data}

Pelaksannan penelitian ini pertama-tama pengumpulan data-data terhadap lokasi penelitian untuk mendapatkan data lapisan tanah dari sumur bor di tempat studi kasus/proyek dengan metode geofisika dengan resistiviy image dan pemboran. Selain itu juga dapat dilakukan dengan melakukan korelasi-korelasi antara data yang tersedia (map hidrogeologi) untuk daerah penelitian FBS/D. Disamping itu diperlukan data air sungai, danau dan air tanah dangkal pada lokasi penelitian, sekeliling lokasi penelitian untuk kelengkapan data.

Tahap selanjutnya dilakukan pemilihan lokasi untuk pemboran sumur FBS/D untuk analisis laboratorium terhadap kualitas air sungai tersebut serta persiapan tempat studi kasus/proyek yang digunakan dalam penelitian ini adalah berdasarkan desain proyek nyata dari FBS/D (2 lokasi dengan daerah yang berbeda) yang mempunyai masalah tentang kebutuhan air minum.

Pelaksanaan penelitian untuk 2 lokasi yang berbeda dengan mempersiapkan sumur bor penelitian serta pelaksanaan nya dan analisis kualitas air serta analissis isotope stabil yang menghasilkan data yang dibutuhkan untuk keseluruhannya.

Pengambilan sampel air dapat dilakukan pada setiap sumur setelah air sumur bor dikuras hingga tiga kali volume pipa untuk mengurangi kesalahan dan kontaminasi sampel air. Sedangkan untuk kedalaman sumur yang dibor lebih dari 9 meter dari permukaan tanah, karena bakteri Escherichia coli akan hilang pada kedalaman lebih dari 9 meter. Pembersihan sebanyak 3 kali volume air di lubang sumur dilakukan setiap kali sebelum pengambilan sampel untuk menghilangkan genangan air untuk mendapatkan sampel air tanah yang representatif. Sampel botol dan dikirim ke laboratorium di simpan dalam penyimpanan pendingin untuk analisis setelah pengambilan sampel kecuali untuk analisis mikrobiologi (E.Coli) yang harus langsung dikirim ke laboratorium untuk analisis. Sifat fisikokimia diuji menggunakan alat ukur parameter $\mathrm{pH}$ dan TDS selama pengambilan sampel. Analisis sampel air dilakukan dengan menggunakan analisis hantaran lisrtrik (konduktivitas) untuk TDS dan bakteri (E. coli) untuk analisis mikrobiologi.

Untuk memberikan informasi tentang karakteristik akuifer yang diperlukan untuk pengembangan air tanah dangkal, tes pemompaan dilakukan di lokasi yang berbeda. Parameter dari akuifer seperti penarikan dan pemulihan transmisivitas, kapasitas spesifik, ketebalan akifer, dan koefisien penyimpanan yang berasal dari tes pemompaan yang dievaluasi dan dijelaskan dalam makalah ini. Evaluasi ini akan memberikan informasi hidrogeologi yang diperlukan yang akan membantu kita memahami potensi akuifer, sehingga kita dapat menemukan potensi zona air tanah dangkal untuk pembangunan. Metode uji pemompaan biasanya lebih disukai untuk 
pengembangan air tanah dangkal dan menentukan karakteristik akuifer. Dalam penelitian ini, tes pemompaan dilakukan pada 3 sumur terbuka di area studi, semua parameter akuifer penting, seperti hidraulik konduktivitas dan transmisivitas (T) telah digunakan. dihitung menggunakan metode Cooper-Jacob dan Chow. Koefisien penyimpanan, hasil optimum, waktu pemulihan, dan ketebalan akuifer dihitung dari data pengukuran penarikan dan pemulihan, dimensi sumur, ketinggian air, dan debit. Transmisivitas dapat membantu kita memahami potensi air tanah dangkal untuk pengembangan air tanah dangkal.

\section{Hasil dan Pembahasan}

\subsection{FBS dengan lokasi di Alor Pongsu, Malaysia}

Penelitian FBS pada lokasi ini telah dilakukan pengujian dengan Resistivity Image dengan hasil ditunjukan oleh Gambar 4 yang dibandingkan hasil pemboran dengan memperlihatkan lapisan pasir lokasi penelitian pada Gambar 5 berikut:

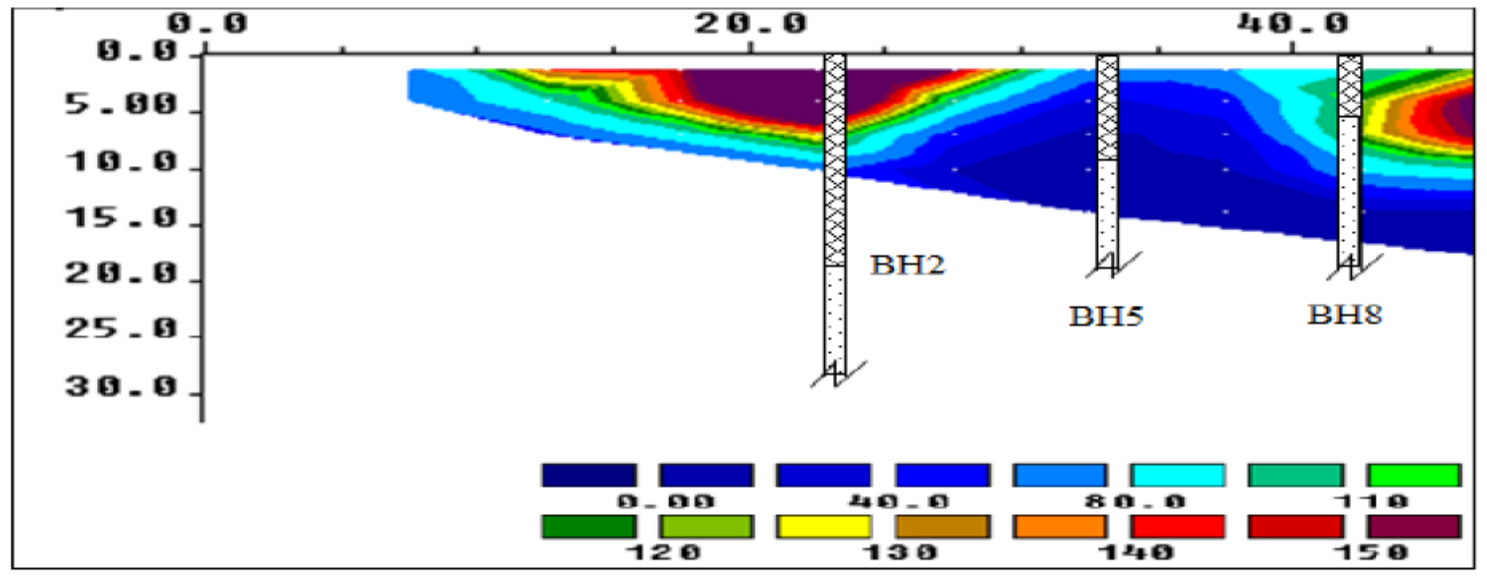

Gambar 4. Profil Resistivitas dengan menempatkan lokasi sumur BH2, BH5 dan BH8 (Leong et al. 2014)

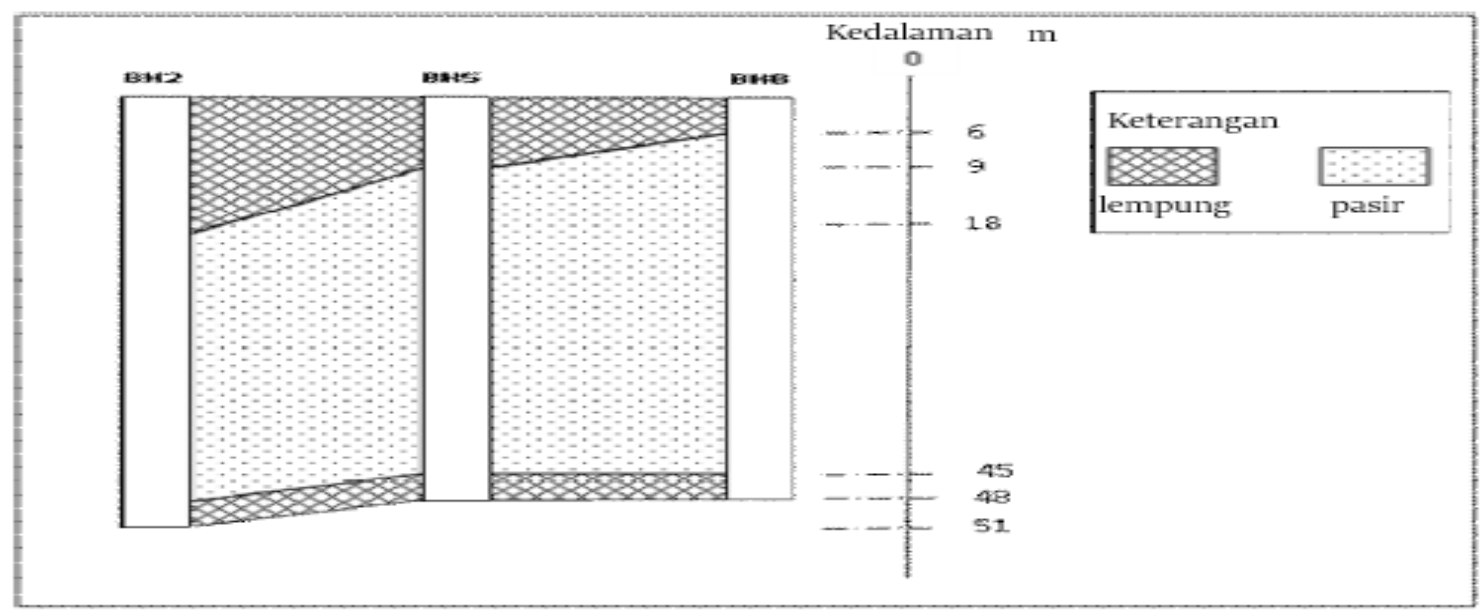

Gambar 5. Litologi lokasi peenelitian Alor Pungsu

Dapat dlihat pada gambar diatas bahwa $\mathrm{BH} 2$ pada kedalaman 0-18 m memiliki resistivitas yang sesuai dengan lapisan lempung tetapi pada kedalaman lebih dari 18 adalah lapisan pasir , tidak detail tersedia karena keterbatasan data resistivitas. Untuk BH5, pada kedalaman 0-9 m, nilai resistivitas yang sesuai dengan menjadi tanah lempung dan selanjutnya lapisan pasir sampai dengan kedalaman 48 m. Sementara untuk BH8, hingga kedalaman 6 terdapat lapisan 
Jurnal SEOI - Fakultas Teknik Universitas Sahid Jakarta

Vol 1 edisi 1 tahun 2019

lempung yang diikuti dengan lapisan pasir sampai kedalaman $45 \mathrm{~m}$ yang disimpulkan merupakan lapisan pasir, yang disebut sebagai lapisan akuifer dangkal atau air tanah dangkal.

\section{a. Karakteristik fisika-kimia air}

Analisis fisika-kimia yang diperoleh menunjukkan parameter seperti $\mathrm{pH}$, suhu (oC) dan Total Dissolved Solid (TDS) seperti yang ditunjukkan pada Tabel 2. Kedua parameter $\mathrm{pH}$ dan suhu untuk air sungai diamati bervariasi sementara tetap konsisten untuk air sumur bor. EC dan Parameter TDS juga relatif tinggi dalam air sumur bor dibandingkan dengan air sungai dan kecenderungan peningkatan nilai diamati ketika membandingkan parameter untuk $\mathrm{BH} 2$ dan BH8. Pencampuran infiltrasi air sungai diperlihatkan oleh nilai-nilai TDS di air sumur bor dengan pengamatan perubahan konsentrasi oleh pengaruh air sungai yang diperlihatkan oleh perubahan Nilai TDS terhadap jarak yang semangkin jauh semangkin meningkat.

Tabel 1. Hasil Analisis fisika kimia Sample Juli 2011di Alor Pongsu

\begin{tabular}{lllll}
\hline Sampel & pH & TDS $(\mathbf{p p m})$ & Suhu ${ }^{\circ} \mathbf{C}$ & $\begin{array}{l}\text { Jarak dari } \\
\text { tepi sungai }\end{array}$ \\
\hline Sungai & 4,2 & 61 & 21.45 & \\
\hline BH2 & 8.56 & 282 & 19.3 & $23 \mathrm{~m}$ \\
\hline BH5 & 8.58 & 268 & 20.8 & $33 \mathrm{~m}$ \\
\hline BH8 & 8.52 & 520 & 21.3 & $42 \mathrm{~m}$ \\
\hline
\end{tabular}

\section{b. Analisis Mikrobiologi (E. coli) Air Alor Pungsu}

Sungai ditemukan mengandung E. Coli dengan nilai MPN ( most probable number) yang tinggi yang disebutkan di atas batas 5000 MPN / 100 ml. Hasil enumerasi bakteri seperti yang ditunjukkan pada Tabel 3 menunjukkan bahwa bakteri berhasil dihilangkan di BH 5 dan BH8 di mana tidak ada bakteri ditemukan dalam sampel air. Namun $\mathrm{BH} 2$ mengandung sedikit bakteri dalam kisaran 200-500 MPN / $100 \mathrm{ml}$ sampel (Tabel 2). Hal ini disebabkan tinggi muka air yang kurang dari $9 \mathrm{~m}$.

Tabel 2. Kandungan E. Coli untuk sampel Alor Pungsu.

\begin{tabular}{lcccc}
\hline \multirow{2}{*}{ Sampel } & \multicolumn{4}{c}{ Bateria E, Coli ( mpn/100ml) } \\
\cline { 2 - 5 } & Juni 2011 & Agustus 2011 & Maret 2012 & Juli 2012 \\
\hline Sungai & 7000 & 3100 & 4600 & 5000 \\
\hline BH2 & 200 & 500 & 310 & 230 \\
\hline BH5 & 0 & 0 & 0 & 0 \\
\hline BH8 & 0 & 0 & 0 & 0 \\
\hline
\end{tabular}

Hasil untuk uji akuifer menunjukkan bahwa lapisan akuifer memiliki nilai konduktivitas hidrolik, K dalam kisaran 6,24-14,18 m/hari yang merupakan karakteristik kecepatan aliran air tanah dangkal lapisan pasir seperti yang ditunjukkan pada Tabel 4. Lubang bor dekat sungai (BH2) memiliki nilai K lebih tinggi dari lubang bor yang jauh dari pinggir sungai (BH8) kecuali untuk BH5 yang memiliki nilai K tertinggi dan diperkirakan akan terhubung ke lapisan badan air bawah permukaan lainnya (Tabel 3).

Tabel 3. Karakteristik yang didapat dari Uji pemompaan

\begin{tabular}{lccc}
\hline Kode Sumur & $\begin{array}{c}\text { Ketebalan } \\
\text { akuifer }(\mathbf{m})\end{array}$ & $\begin{array}{c}\text { Transmissivitas } \\
\left(\mathbf{m}^{2} / \mathbf{d a y}\right)\end{array}$ & $\begin{array}{c}\text { Konduktivitas } \\
\text { Hidrolika }(\mathbf{m} / \mathbf{h a r i})\end{array}$ \\
\hline BH2 & 30 & 329,41 & 10,98 \\
\hline BH5 & 36 & 510,55 & 14,18 \\
\hline BH8 & 39 & 243,19 & 6,24 \\
\hline
\end{tabular}


Jurnal SEOI - Fakultas Teknik Universitas Sahid Jakarta

Vol 1 edisi 1 tahun 2019

\subsection{FDB dengan lokasi Kampus ISTN-Jakarta}

Penelitian lokasi ini membahas tentang hasil yang diperoleh dari karya-karya uji laboratorium. Pembahasan dibagi menjadi tiga bagian, yaitu (1) penelitian water quality index, (2) penelitian hubungan antara air danau/situ dan air sumur penduduk disekitar lokasi penelitiaan dan penelitian bantaran situ dan kali yang terdapat di lingkungan Institut Sains dan Teknologi Nasional. Kualitas air sumur bor yang disiapakan dianalisis terutama untuk nilai $\mathrm{pH}$, konduktivitas dan TDS. Hasilnya dibandingkan dengan temuan dari penelitian yang dilakukan sebelumnya dan juga dibandingkan dengan pedoman. Disamping itu dilakukan penelitian terhadap lapisan akuifer dangkal pada sumur bor yang telah disiapkan.

\section{a. Hubungan Air Situ dengan Air tanah dangkal di sekitar Lingkungan ISTN}

Penelitian menggunakan pendekatan isotop stabil O-18 dan Deuterium menunjukan antara air Situ ISTN dan sumur2 bor yang terdapat dissekitar ISTN yang diduga airnya berasal dari Danau ISTN yang telah dilakukan verifikasi dengan O-18 dan Deuteriun yang mempunyai korelasi yang sangat baik secara statistik

Pengambilan sampel air terdiri dari air Danau ISTN, Setu Babakan dan air tanah dari sumur-sumur penduduk dan warung disekitar danau tersebut. Dari penentuan lokasi-lokasi area yang telah diambil sampel airnya. Untuk Air Tanah di Sekitar Danau ISTN dan Setu Babakan. Pada setiap titik area, pengambilan sampel dilakukan hanya satu kali.Total area yang didapat ada 10 titik dengan 10 sampel air yang diambil. Adapun keterangan data sampel air tanah di tiap lokasi dapat dilihat pada Tabel 4 dan 5 dibawah ini.

Tabel 4. Data Sampel Air Tanah di Tiap Lokasi

\begin{tabular}{llllll}
\hline $\begin{array}{c}\text { Titik Area Pengambilan } \\
\text { Sampel Air Tanah Danau } \\
\text { ISTN dan Setu Babakan }\end{array}$ & $\begin{array}{c}\text { Waktu } \\
\text { Pengambilan }\end{array}$ & pH & $\begin{array}{c}\text { Suhu } \\
\left({ }^{\mathbf{0}} \mathbf{C}\right)\end{array}$ & $\begin{array}{c}\text { Electric } \\
\text { Conductiv } \\
\text { ity (ms) }\end{array}$ & $\begin{array}{c}\text { Total Dissolve } \\
\text { Solid (part per } \\
\text { trilion) }\end{array}$ \\
\hline Masjid setu babakan & 29-Des-16 & 4,87 & 28 & 0,5 & 0,28 \\
\hline Warung kopi setu babakan & 29-Des-16 & 4,76 & 29,5 & 0,21 & 0,1 \\
\hline Pos ronda setu babakan & 29-Des-16 & 4,46 & 29,6 & 0,37 & 0,18 \\
\hline Klinik setu babakan & 29-Des-16 & 5,48 & 30,7 & 0,12 & 0,05 \\
\hline Rumah warga setu babakan & 29-Des-16 & 6,83 & 30,1 & 0,34 & 0,16 \\
\hline Kosan okky & 06-Jan-17 & 6,01 & 31,1 & 0,41 & 0,21 \\
\hline Warung kopi juber & 06-Jan-17 & 6,46 & 30,4 & 0,27 & 0,12 \\
\hline Warung kopi kumis & 06-Jan-17 & 7 & 30,5 & 0,09 & 0,04 \\
\hline Masjid bilal & 06-Jan-17 & 4,68 & 31,2 & 0,24 & 0,1 \\
\hline Rumah putri & 06-Jan-17 & 4,74 & 34,2 & 0,2 & 0,1 \\
\hline
\end{tabular}

Tabel 5. Hasil Pengolahan Data dari Analisa Sampel Air dengan Spektrometer Laser

\begin{tabular}{llll}
\hline Sampel & Simbol & $\boldsymbol{\delta D}$ permil & $\boldsymbol{\delta}^{\mathbf{1 8}} \mathbf{O}$ permil \\
\hline Pinggir Danau ISTN & D1 & $-47,0 \pm 2,0$ & $-6,23 \pm 0,19$ \\
\hline Tengah Danau ISTN & D2 & $-44,2 \pm 1,7$ & $-6,16 \pm 0,20$ \\
\hline Ujung Danau ISTN & D3 & $-42,7 \pm 1,2$ & $-6,38 \pm 0,57$ \\
\hline Pinggir Setu Babakan & S1 & $-36,6 \pm 0,8$ & $-5,56 \pm 0,17$ \\
\hline Tengah Setu Babakan & S2 & $-37,4 \pm 0,2$ & $-5,02 \pm 0,23$ \\
\hline Ujung Setu Babakan & S3 & $-39,8 \pm 2,7$ & $-4,32 \pm 0,24$ \\
\hline
\end{tabular}


Jurnal SEOI - Fakultas Teknik Universitas Sahid Jakarta

Vol 1 edisi 1 tahun 2019

\begin{tabular}{|c|c|c|c|}
\hline Sampel & Simbol & $\delta \mathrm{D}$ permil & $\delta^{18} \mathrm{O}$ permil \\
\hline Masjid setu babakan & $\mathrm{R} 1$ & $-43,7 \pm 1,1$ & $-5,23 \pm 0,22$ \\
\hline Warung kopi setu babakan & $\mathrm{R} 2$ & $-40,4 \pm 0,5$ & $-5,42 \pm 0,18$ \\
\hline Pos ronda setu babakan & R3 & $-37,4 \pm 0,8$ & $-4,89 \pm 0,39$ \\
\hline Klinik setu babakan & $\mathrm{R} 4$ & $-43,6 \pm 1,6$ & $-5,73 \pm 0,33$ \\
\hline Rumah warga setu babakan & R5 & $-40,2 \pm 2,2$ & $-6,25 \pm 0,05$ \\
\hline Kosan okky & R6 & $-42,4 \pm 0,3$ & $-7,25 \pm 0,20$ \\
\hline Warung kopi juber & R7 & $-48,9 \pm 0,7$ & $-8,67 \pm 0,32$ \\
\hline Warung kopi kumis & $\mathrm{R} 8$ & $-39,7 \pm 1,0$ & $-7,11 \pm 0,12$ \\
\hline Masjid bilal & R9 & $-41,4 \pm 1,9$ & $-6,72 \pm 0,35$ \\
\hline Rumah putri & $\mathrm{R} 10$ & $-45,5 \pm 1,9$ & $-7,18 \pm 0,30$ \\
\hline
\end{tabular}

Selanjutnya setelah dilakukan analisis statistik menggunakan pendekatan $t_{\text {student }}$ test dengan tingkat kepercayaan $95 \%$ didapatkan batas atas dan batas bawah seperti diperlihatkan pada Gambar 6 dan terlihat bahwa plotting data berada pada daerah di sepanjang garis regresi linier sampel yang diambil disekitar danau ISTN dan situ Babakan. Artinya, sumber air tanah dan air danau berasal dari satu sumber yang sama. Pada hasil plotting data sampel air Danau ISTN dan Setu Babakan, nilai $\delta$ yang diperoleh masih menunjukkan nilai didalam batas atas dan batas bawah yang menunjukkan hubungan antara air danau/situ dengan air tanah sekitarnya.

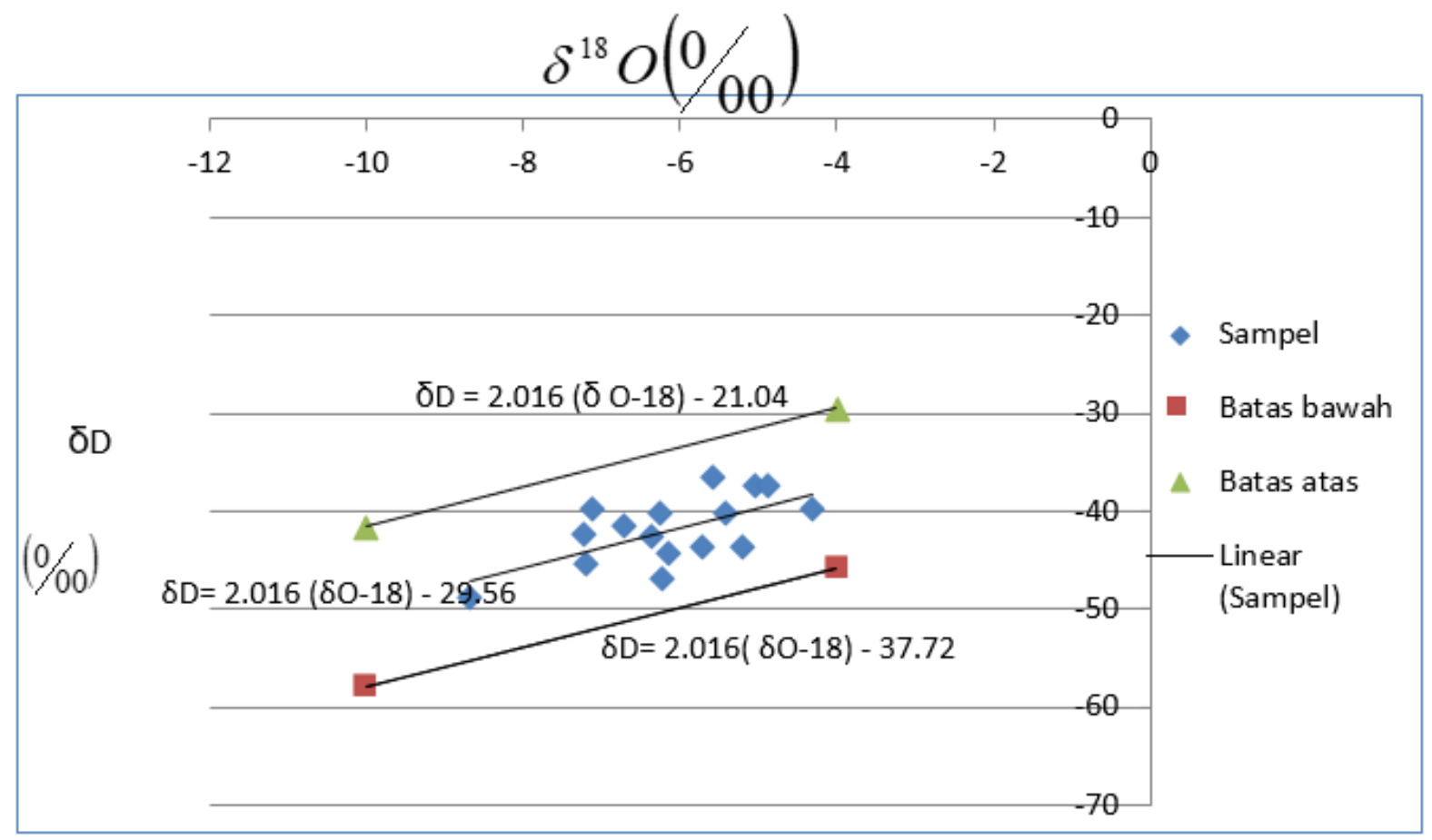

Gambar 6. Hubungan antara $\delta^{18} \mathrm{O}$ dan $\delta \mathrm{D}$ (Deuterium) dari sampel air di lingkungan danau ISTN dan Situ Babakan.

\section{b. Litologi lapisan di Kampus ISTN.}

Pelaksanaan pelaksanaan penelitian ini telah dilakukan dengan pendekatan metode pemboran dengan hasil ditunjukan oleh gambar dibawah yang menjelaskan litologi lapisan. Dalam penelitian ini dilakukan pengeboran pada 12 titik, dimana 3 sumur bor berada dibantaran kali ISTN dengan diameter pipa PVC 4 inch dan 3 sumur pantau di setiap sumur utama dengan diameter pipa PVC 2 inch. Selanjutnya 3 sumur bor yang berada di bantaran danau/ situ ISTN dengan diameter 4 inch dan 3 sumur pantau dengan diameter 2 inch. Sumur pantau tersebut terletak 1 meter dari masing-masing sumur bor. Jarak rencana sumur adalah 10 meter dari bibir kali, selanjutnya untuk sumur bor berikutnya berjarak 10 meter dari sumur pertama dan terakhir 
Jurnal SEOI - Fakultas Teknik Universitas Sahid Jakarta

Vol 1 edisi 1 tahun 2019

sumur ketiga berjarak 10 meter dari sumur kedua. Pengeboran direncanakan sedalam 20 meter atau bila mata bor sudah menyentuh lapisan pasir, jadi bila pada kedalaman 20 meter mata bor belum menyentuh pasir maka pengeboran tetap di lanjutkan sampai melewati lapisan pasir seperti terlihat pada Gambar 7 dan 8 dibawah ini.

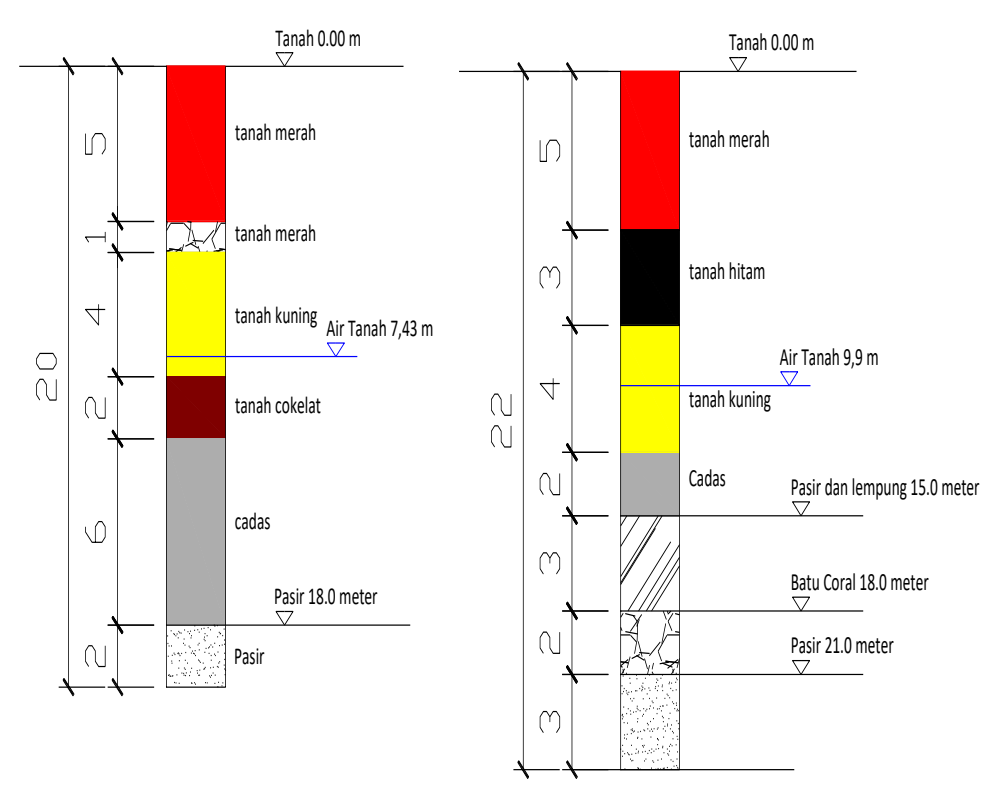

BH1.1

BH1.2

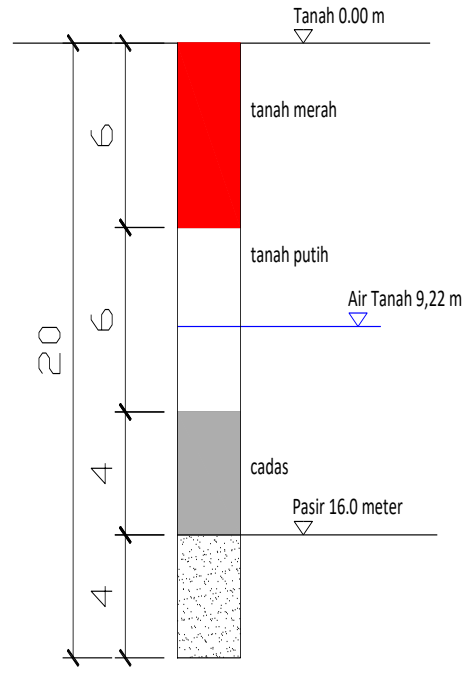

BH1.3

Gambar 7. Litologi BH 1.1 ,BH 1.2 dan BH 1.3

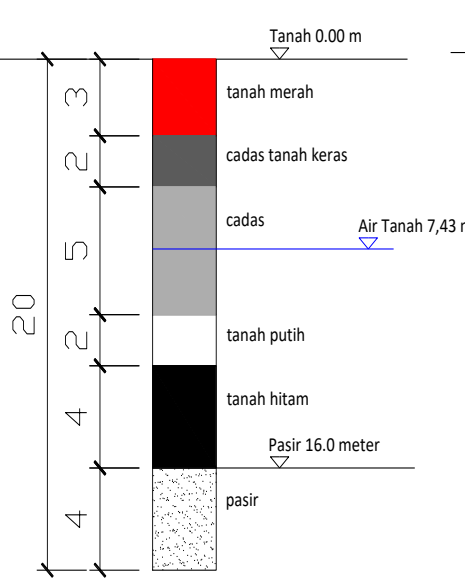

BH2.1

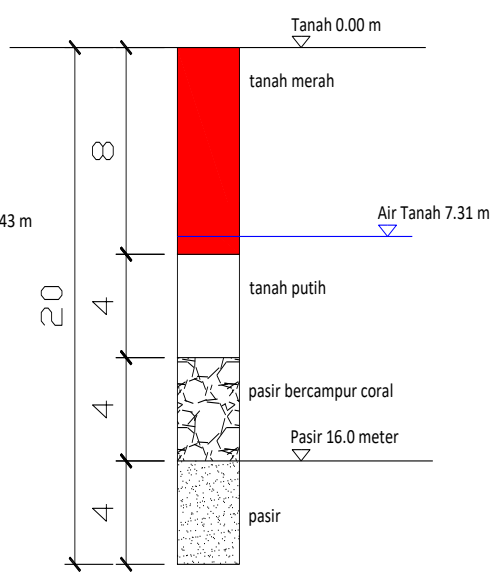

BH 2.2

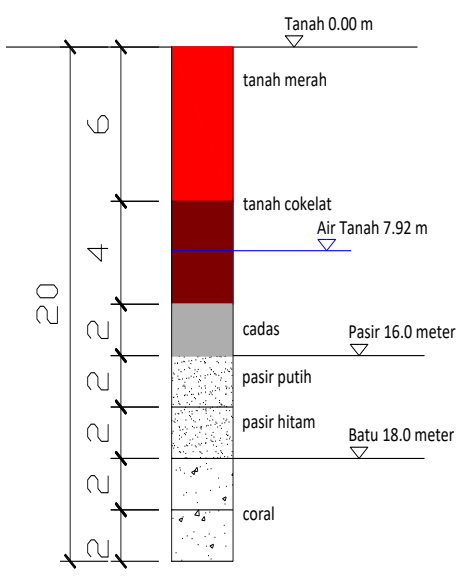

$\mathrm{BH} 2.3$

Gambar 8. Litologi titik BH 2.1, BH2.2 dan BH2.3

Dari gambar Litologi diatas memperlihatkan lapisan air tanah dangkal (aquifer dangkal) terdapat pada kedalaman 18 meter, 19 m dan 16 meter yang masing-masing untuk BH1.1, BH1.2 dan BH1.3. Sedangkan pada BH2.1, BH2.2 dan BH 2.3 memperlihatkan lapisan litologi berturut-turut $16 \mathrm{~m}, 16 \mathrm{~m}$ dan $12 \mathrm{~m}$ yang menunjukan potensi dari air tanah dangkal yang terdapat pada 6 sumur bor tersebut diatas 
Jurnal SEOI - Fakultas Teknik Universitas Sahid Jakarta

Vol 1 edisi 1 tahun 2019

\section{c. Transmisivitas dan konduktivitas Hidrolika}

Transmisivitas dan konduktivitas hidrolika adalah salah satu data hidrogeologi yang paling penting yang diperlukan untuk mengelola sumber daya air tanah. Transmisivitas menggambarkan kemampuan umum akuifer untuk mengirimkan air ke seluruh lapisan akuifer, sementara konduktivitas hidrolik mengukur kemampuan ini berdasarkan satuan luas. Kondisi hidrogeologi di daerah tersebut telah dievaluasi berdasarkan hasil uji pemompaan seperti pada table berikut:

Tabel 6. Hasil Konduktivitas Hidrolika dan Transmissivitas

\begin{tabular}{llll}
\hline Pumping Test & $\begin{array}{l}\text { T } \\
\left(\mathbf{m}^{2} / \mathbf{d a y}\right)\end{array}$ & S & $\begin{array}{l}\text { K } \\
(\mathbf{m} / \mathbf{d a y})\end{array}$ \\
\hline BH 2.1 & 20.32 & 0.00026 & 5.08 \\
\hline BH 2.2 & 24.63 & 0.0090 & 6.16 \\
\hline BH 2,3 & 90.02 & 0.0318 & 22.51 \\
\hline
\end{tabular}

Dalam akuifer bebas, koefisien penyimpanan sesuai dengan hasil spesifiknya. Untuk akuifer bebas, ini hanya diekspresikan oleh produk volume akuifer yang tergeletak di antara permukaan air di awal dan di akhir periode waktu tertentu dan hasil rata-rata spesifik dari formasi. Selain itu, storativitas biasanya bervariasi langsung dengan ketebalan akuifer, dan tergantung pada ukuran butir, bentuk dan distribusi pori-pori, pemadatan stratum, dan waktu debit. Di area studi, hasil menunjukkan bahwa koefisien penyimpanan bervariasi dari nilai 0,00026 hingga 0,0316 dengan rentang normal antara 0,01 hingga 0,35 (Kumar et al., 2014)

Transmisivitas didefinisikan sebagai tingkat di mana air kekentalan kinematik yang berlaku ditularkan melalui lebar unit akuifer di bawah satuan gradien hidrolika (Todd 1980). Transmisivitas tanah atau batu juga tergantung pada berbagai faktor fisik, termasuk porositas, ukuran partikel, dan distribusi dan pengaturan partikel

\section{d. Analisis Mikrobiologi, pH dan TDS}

Berdasarkan analisis bakteri E coli dan TDS untuk pengambilan sampel yang diambil dari $\mathrm{BH} 2.1, \mathrm{BH} 2.2$, dan $\mathrm{BH} 2.3$ dengan jarak sekitar 10, 20, $30 \mathrm{~m}$ dari batas danau ditemukan dalam klasifikasi air tawar dengan populasi mikroba patogen nol untuk jarak 10,20 dan $30 \mathrm{~m}$ dari batas danau. Dari hasil yang diperoleh sampel air sebagai klass kategori A. Dari sudut pandang E Coli, air bisa dikonsumsi tanpa pengobatan. Hasilnya ini berhubungan dengan hasil yang diperoleh dari penyelidikan potensi air tanah dangkal melalui filtrasi bantaran Sungai untuk daerah Alur Pongsu, Malaysia dalam pengembangan sumberdaya air, yang dapat dijelaskan sebagai bahwa pengambilan air untuk tujuan FBS/D yang terbaik adalah pada jarak lebih darai 10 meter baik secara horizontal dari tepi sungai /danau maupun secaraa vertikal kebawah dari permukaan tanah (lihat pada Tabel dibawah ini).

Tabel 7. Hasil analalisis dari TDS, pH dan bakteri E. Coli

\begin{tabular}{llllll}
\hline No. & Kode Sampel & TDS (mg/L) & $\mathbf{p H}$ & Hasil MPN/100ml & $\begin{array}{l}\text { Jarak dari tepi danau } \\
(\mathbf{m})\end{array}$ \\
\hline 1 & BH 2.1 & 104 & 5.14 & 0 & 10 \\
\hline 2. & BH 2.2 & 105 & 4.87 & 0 & 20 \\
\hline 3 & BH 2.3 & 187 & 4.82 & 0 & 30 \\
\hline 4 & Danau ISTN & 70.5 & 6.74 & 1650 & danau \\
\hline 5 & Danau ISTN & 70.5 & 6.74 & 850 & danau \\
\hline
\end{tabular}


Jurnal SEOI - Fakultas Teknik Universitas Sahid Jakarta

Vol 1 edisi 1 tahun 2019

Dari hasil TDS menunjukkan air danau bergerak dari danau ke sekitar bank yang menunjukkan peningkatan TDS dari $\mathrm{BH} 2,1$ hingga $\mathrm{BH} 2,3$ dan $\mathrm{BH} 1,3$ hingga $\mathrm{BH} 1,1$ secara beturut-turut (lihat Tabel 7)

\section{Kesimpulan}

Pemboran sumur merupakan metode yang efektif untuk FBS dan FBD sebagai prediksi lapisan akuifer dan tes pemompaan untuk mempelajari potensi FBS/D di wilayah studi yang berpotensi baik. Hasil juga menunjukkan bahwa mikrobiologi, dan TDS menunjukkan bahwa air tanah dangkal dapat diklasifikasikan sebagai kelas A kecuali untuk pH sampel dari bank yang harus ditingkatkan sebelum konsumsi apabila pengambilan air diambil pada jarak lebih 10 meter baik secara horizontal dari tepi sungai dan vertikal kebawah dari permukaan air tanah.

\section{Daftar Pustaka}

Clark, I. D., \& Fritz, P. (1997). Environmental isotopes in hydrogeology. New York: Lewis Publishers

Hunt, R. J., T. B. Coplen, N. L. Haas, D. A. Saad, M. A. Borchardt., J Hydrol. (2004). 302:154172 Elsevier.

Kumar T. Jeyaavel Raja, A. Balasuramanian, R. S. Kumar, C. Dushiyan than, B. Thirumeelakandan, R. Suresh. K. Karthikeyan, D. Davidraju, (2016). Appl Water Sci 6: 179-186.

Leong C. S., S. Syafalni, Abustan I, Abdullah R. (2014) Shallow Groundwater potential through Riverbank Filtration for Water Resources Development, IJAES, 9, 5 , 2639-2651.

Marsiano W., S. Syafalni, W. Kuswaya, M. Falaqi Djamhuri, and BungKus Praktikno. (2018). The interrelationship between ISTN lake, Babakan lake and the surrounding wells of shallow groundwater using stable isotopes $\delta{ }^{2} \mathrm{H}$ and $\delta{ }^{18} \mathrm{O}$ for the lake bank filtration potential, MATEC Web Conferences 195, 05005.

Schmidt, C. K., F. T. Lange, H-J Brauch, W. Kuhn. (2003). "Experiences with riverbank filtration and infiltration in Germany". DVGW-Water Technology Centre (TZW), Germany.

Shamrukh, M., A. Abdel-Wahab., (2008). Clean Techn Environ Policy 10:351-358.

Todd TK (1980), Groundwater hydrology, Wiley, New York

Weiss, W. J., E. J. Bouwer, W. P. Ball, C.R. O’Melia, M.W. LeChevallier, H. Arora, R. Aboytes, T.F. Speth., GRA , 5, 04297 (2003).

Wu Y, Hui L, Wang H, Li Y, Zeng R. (2006). "Effectiveness of riverbank filtration for removal of nitrogen from heavily polluted rivers: a case study of Kuihe River, Xuzhou, Jiangsu", China. 